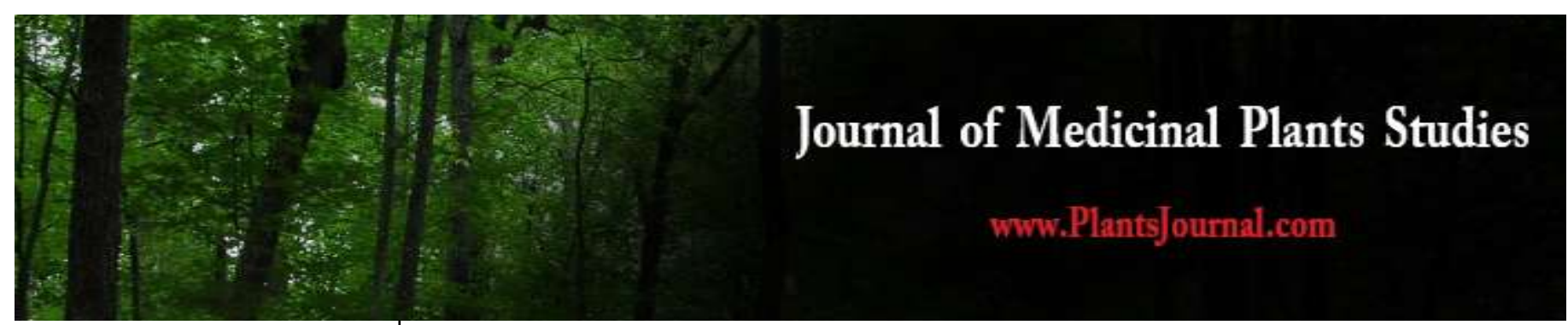

ISSN (E): 2320-3862

ISSN (P): 2394-0530

NAAS Rating: 3.53

www.plantsjournal.com

JMPS 2021; 9(3): 168-170

(C) 2021 JMPS

Received: 23-03-2021

Accepted: 27-04-2021

Sujata MP

Mycology and Plant Pathology

Laboratory, Department of P.G and Research in Botany,

Gulbarga University,

Kalaburagi, Karnataka, India

Corresponding Author:

Sujata MP

Mycology and Plant Pathology

Laboratory, Department of P.G

and Research in Botany,

Gulbarga University,

Kalaburagi, Karnataka, India

\section{In vitro study of Eruca sativa Mill., seeds in Kalaburagi region, Karnataka, India}

\section{Sujata MP}

DOI: https://doi.org/10.22271/plants.2021.v9.i3b.1286

\section{Abstract}

Eruca sativa Mill., a plant belonging to family Brassicaceae commonly used as salad vegetable. The cultivation of Eruca sativa plant has most of the Mediterranean countries. Since ancient time Eruca sativa is used for medicinal and commercial plant. It has highest nutrients and minerals. The present study reveals that the germination of Eruca sativa seeds on medium by vitro condition. It shows that there is good germination short interval of harvested seeds than the long day stored seeds.

Keywords: In vitro, Seeds, PDA medium, Eruca sativa, Kalaburagi

\section{Introduction}

Eruca sativa is an endemic species of the Brassicaceae family which produced mostly in Mediterranean countries such as Italy, Greece and Turkey. The common name of Eruca sativa is of various Viz., Rocket, Gergeer, Jarjeer, Taramera, etc,. It is a dark green annual plant, about 20 to $50 \mathrm{~cm}$ in height, with a spicy-pungent taste ${ }^{[1,2]}$. Since ancient times, the rocket plant has been a source of nutrition, an aphrodisiac and a medical plant, and has other uses ${ }^{[3]}$. The study of Eruca sativa seeds germination and affected fungi determined in this experiment.

\section{Materials and methods}

Kalaburagi is a semiarid region of the Deccan plateau of north-eastern district of Karnataka. Gulbarga University $\left(17^{\circ} 18^{\prime} 46.62^{\prime \prime} \mathrm{N}, 76^{\circ} 52^{\prime} 27.32^{\prime \prime} \mathrm{E}\right)$ situated $10 \mathrm{~km}$ away from the city. The experimental field is located at Department of Botany, Gulbarga University, Kalaburagi. Eruca sativa seeds sample were collected from Saudi Arabia. These Saudi seeds were cultivated in the open field department of Botany, Gulbarga University, Kalaburagi. After the harvest of the Eruca sativa, the newly seeds were named as Indian seeds. From both seeds, the experiments of study of germination of seeds on PDA medium was carried out in Mycology and Plant pathology laboratory, department of Botany, Gulbarga University, Kalaburagi.

Saudi seeds and Indian seeds of Eruca sativa samples were initially subjected to surface sterilization with absolute sterile distilled water. The seeds samples were incubated in Petri plate on PDA medium at room temperature for 5-7 days and observed daily. Then, calculate the number of germination of seeds at $3^{\text {rd }}$ day and $5^{\text {th }}$ day of experiment and observed the fungi affected on seeds during the experiment.

\section{Results and Discussion}

An experiment was conducted on both Indian and Saudi seeds on PDA medium. Total 100 seeds of Saudi and 100 seeds of Indian selected to incubate on 10 Petri plates of 20 seeds per plate. The germination data are record every 24 hours of interval then find out the mean value on $3^{\text {rd }}$ and $5^{\text {th }}$ day. After $5^{\text {th }}$ day, the complete growth of pathogens in the petriplate observed.

The number of germination in Indian seeds and Saudi seeds are $66 \%$ and $28 \%$ and affected by fungi on 20 and 18 seeds on $3^{\text {rd }}$ day of observation. Whereas, the germinated of Indian seeds and Saudi seeds are $24 \%$ and $18 \%$ and affected by fungi on 79 and 99 seeds at $5^{\text {th }}$ day. Aspergillus niger, A. flavus, A. fumigates, Pencillium sp., Neurospora sp., fungi are associated, with Indian seeds and A. niger, A. flavus, A fumigates, Mucor sp., Pencillium sp., with Saudi seeds (Table $1 \& 2$ ). So, it shows that, the gradually decreased in seed germination and loss of seed viability by affecting the different fungi. 
The review of literature shows that, the seed germination is one of the biological processes most sensitive to stress conditions particularly salt stress.

For chromosomal study of Rocket, the seeds were germinated on moist filter paper in Petri dishes kept in the dark at room temperature ${ }^{[4]}$. Taramira seeds can be stored at room temperature for two seasons and it maintains the population structure by lessening generation interval ${ }^{[5]}$. The leaves of Eruca sativa used as salad and medicines for stimulant, stomachic, diuretic, and antiscorbutic activity ${ }^{[6]}$. Tissue culture techniques of genetic improvement, the Eruca sativa cultivars are grows from seeds or transplants. Seeds are sown 0.5 to $1 \mathrm{~cm}$ deep in rows 15 to $20 \mathrm{~cm}$ apart. Soaking of seeds of $E$. sativa in water for $6 \mathrm{~h}$ and then sowing in the evenings for improved germination ${ }^{[7]}$. The mucilaginous seeds of $E$. sativa used as biocontrol agent for the larvae of the insect Culex quinquefasciatus and Aedes aegypti ${ }^{[8]}$. The seed mucilage of $E$. sativa plant was described to have great potential as a commercial hydrocolloid in food industry [9]. The nutrient elements in Eruca sativa was found as $4.32 \% \mathrm{~N}$, $0.25 \% \mathrm{P}, 5.13 \% \mathrm{~K}, 2.95 \% \mathrm{Ca}, 0.58 \% \mathrm{Mg}, 799.88 \mathrm{mgkg}-1 \mathrm{Na}$, $350 \mathrm{mgkg}-1 \mathrm{Fe}, 5.36 \mathrm{mgkg}-1 \mathrm{Cu}, 40.58 \mathrm{mgkg}-1 \mathrm{Mn}$ and 64.86 mgkg-1 $\mathrm{Zn}{ }^{[10]}$. The present paper tried to study the germination of seeds in laboratory conditions. So, the comparative study of Indian and Saudi Eruca sativa seeds was reported by in vitro condition during this experiment.

Table 1: The description of number of seeds germination and affected fungi on PDA media

\begin{tabular}{|c|c|c|c|c|c|c|c|}
\hline \multirow{3}{*}{$\begin{array}{l}\text { Plate } \\
\text { No. }\end{array}$} & \multirow{3}{*}{$\begin{array}{l}\text { No. of seeds } \\
\text { incubated on } \\
\text { PDA }\end{array}$} & \multirow{2}{*}{\multicolumn{3}{|c|}{$\begin{array}{c}\text { Indian seeds (IS) } \\
3^{\text {rd }} \text { day }\end{array}$}} & \multirow{2}{*}{\multicolumn{3}{|c|}{$\frac{\text { Saudi seeds (SS) }}{3^{\text {rd }} \text { dav }}$}} \\
\hline & & & & & & & \\
\hline & & $\begin{array}{c}\text { Total } \\
\text { germination } \\
\end{array}$ & $\begin{array}{l}\text { Total effect of } \\
\text { seeds by fungi }\end{array}$ & Name of associated Fungi & $\begin{array}{c}\text { Total } \\
\text { germination } \\
\end{array}$ & $\begin{array}{l}\text { Total effect of } \\
\text { seeds by fungi }\end{array}$ & $\begin{array}{c}\text { Name of associated } \\
\text { Fungi }\end{array}$ \\
\hline 1 & 20 & 16 & 3 & A. niger, Neurospora sp. & 5 & 2 & $\begin{array}{c}\text { A. niger, } \\
\text { Pencillium sp. }\end{array}$ \\
\hline 2 & 20 & 11 & 8 & $\begin{array}{c}\text { A. niger, } \\
\text { A. fumigates, }\end{array}$ & 7 & 5 & \begin{tabular}{|c|} 
A. niger, \\
A. fumigates, Mucor \\
sp.
\end{tabular} \\
\hline 3 & 20 & 12 & 2 & $\begin{array}{l}\text { A. flavus, } \\
\text { Mucor }\end{array}$ & 3 & 5 & $\begin{array}{c}\text { A. niger, } \\
\text { Pencillium sp. }\end{array}$ \\
\hline 4 & 20 & 17 & 1 & A. niger, & 5 & 3 & A. niger, \\
\hline 5 & 20 & 10 & 6 & $\begin{array}{c}\text { A. niger, } \\
\text { Pencillium sp. }\end{array}$ & 8 & 3 & A. fumigates, \\
\hline Total & $100 \%$ & $66 \%$ & 20 seeds & & $28 \%$ & 18 seeds & \\
\hline
\end{tabular}

Table 2: The description of number of seeds germination and affected fungi on PDA media

\begin{tabular}{|c|c|c|c|c|c|c|c|}
\hline \multirow{3}{*}{$\begin{array}{l}\text { Plate } \\
\text { no. }\end{array}$} & \multirow{3}{*}{$\begin{array}{c}\text { No. of seeds } \\
\text { incubated on } \\
\text { PDA }\end{array}$} & \multicolumn{3}{|c|}{ Indian seeds (IS) } & \multicolumn{3}{|c|}{ Saudi seeds (SS) } \\
\hline & & \multicolumn{3}{|c|}{$5^{\text {th }}$ day } & \multicolumn{3}{|c|}{$5^{\text {th }}$ day } \\
\hline & & $\begin{array}{c}\text { Total } \\
\text { germination }\end{array}$ & $\begin{array}{c}\text { Total effect } \\
\text { of seeds by } \\
\text { fungi }\end{array}$ & $\begin{array}{l}\text { Name of } \\
\text { associated } \\
\text { Fungi }\end{array}$ & $\begin{array}{c}\text { Total } \\
\text { germination }\end{array}$ & $\begin{array}{l}\text { Total effect of } \\
\text { seeds by fungi }\end{array}$ & $\begin{array}{l}\text { Name of } \\
\text { associated } \\
\text { Fungi }\end{array}$ \\
\hline 1 & 20 & 5 & 20 & $\begin{array}{c}\text { A. niger, } \\
\text { Pencillium sp. }\end{array}$ & 5 & 20 & $\begin{array}{c}\text { A. flavus, } \\
\text { A. niger, } \\
\text { Pencillium sp. }\end{array}$ \\
\hline 2 & 20 & 3 & 17 & $\begin{array}{c}\text { A. niger, } \\
\text { A. fumigates, } \\
\text { Mucor }\end{array}$ & 2 & 19 & $\begin{array}{c}\text { A. niger, } \\
\text { A. fumigates, } \\
\text { Mucor sp. }\end{array}$ \\
\hline 3 & 20 & 6 & 13 & A. fumigates & 4 & 20 & A. niger, \\
\hline 4 & 20 & 4 & 14 & Mucor sp. & 5 & 20 & $\begin{array}{c}\text { A. niger, } \\
\text { Neurospora sp. }\end{array}$ \\
\hline 5 & 20 & 6 & 15 & Neurospora sp. & 2 & 20 & $\begin{array}{l}\text { A. niger, } \\
\text { Mucor sp. }\end{array}$ \\
\hline Total & $100 \%$ & $24 \%$ & 79 seeds & & $18 \%$ & 99 seeds & \\
\hline
\end{tabular}

\section{Conclusion}

The experiment proves that, the germination of Eruca sativa seeds on PDA medium grows on increase and less affected by fungi after the immediate harvest. But, the seeds are less germinated and high affected by fungi during more interval of time. So it indicates loses the vigor in seeds of Eruca sativa at long time from harvest.

\section{Acknowledgement}

The author is thankful to Chairman and Supervisor, department of Botany, Gulbarga University, Kalaburagi for providing all the facility during the experiment.

\section{References}

1. Morales M, Janick J. Arugula: A promising specialty leaf vegetable. In: Trends in New Crops and New Uses. Janick J, Whipkey A (eds.). Alexandria, VA: ASHS Press
2002, 418-423.

2. Sharma MM, Dhingra M, Dave A, Batra A. Plant regeneration and stimulation of in vitro flowering in Eruca sativa Mill. Afr. J. Biotechnol 2012;11(31):79067911.

3. Yaniv Z, Schafferman D, Amar Z. Traditional uses and biodiversity of rocket (Eruca sativa, Brassicaceae) in Israel. Econ. Bot 1998;52(4):394-400.

4. Blangiforti S, Venora G. Cytological study on Rocket species by means of image analysis system. International Plant Genetic Resources Institute 1997, 36-40.

5. Divakara Sastry EV. Taramira (Eruca sativa) and its Improvement - A Review. Agric. Rev 2003;24(4):235249.

6. Bhandari DC, Chandel KPS. Status of rocket germplasm in India: research accomplishments and priorities. In S. Padulosi, D. Pignone, eds. Rocket: A Mediterranean Crop 
for the World. International Plant Genetic Resource Institute, Rome 1996, 67.

7. Bianco VV. Rocket, an ancient underutilized vegetable crop and its potential. In S. Padulosi, eds. Rocket Genetic Resources Network. Lisbon, Portugal 1995, 35-57.

8. Gajra Garg and Vinay Sharma. Eruca sativa (L.): Botanical Description, Crop Improvement, and Medicinal Properties, Journal of Herbs, Spices \& Medicinal Plants, 2014;20(2):171-182.

9. Koocheki A, Razavi SMA, Hesarinejad MA. Effect of extraction procedures on functional properties of Eruca sativa seed mucilage. Food Biophys 2012;7:84-92.

10. Neriman Tuba Barlas, Mehmet Eref Irget, Mahmut Tepecik. Mineral content of the rocket plant (Eruca sativa) African Journal of Biotechnology 2011;10(64):14080-14082. 